\title{
Isolation and physiological characterization of two novel, piezophilic, thermophilic chemolithoautotrophs from a deep-sea hydrothermal vent chimney
}

\author{
Ken Takai ${ }^{1,{ }^{*}}$ Masayuki Miyazaki ${ }^{1}$, Hisako Hirayama ${ }^{1}$, Satoshi Nakagawa ${ }^{1}$, Joël Querellou ${ }^{2}$ and Anne \\ Godfroy $^{2}$
}

\footnotetext{
${ }^{1}$ Sunground Animalcule Retrieval (SUGAR) Program, Japan Agency for Marine-Earth Science \& Technology, 215 Natsushima-cho, Yokosuka 237-0061, Japan

2 Ifremer, Ctr Brest, Laboratoire de Microbiologie des Environnements Extrêmes, UMR 6197, F-29280 Plouzané, France.
}

\author{
*: Corresponding author : Takai Ken, Tel. (+81) 46867 9677; Fax (+81) 46867 9715, email address : \\ kent@jamstec.go.jp
}

\begin{abstract}
:
Two novel, thermophilic piezophiles, capable of chemolithoautotrophic growth, are successfully cultivated and isolated from a black smoker chimney at the TAG field (Mid Atlantic Ridge: MAR) by using a piezophilic cultivation technique. Both strains (strains 106 and 108) represent dominant cultivated populations of the microbial communities in the chimney surface habitat. Strain 106 represents typically thin, long spiral cells under the piezophilic growth condition but short bent cells under the non-piezophilic condition. It is a strictly chemolithoautotrophic gammaproteobacterium using reduced sulfur compounds as the electron donors, and nitrate and $\mathrm{O}_{2}$ as the electron acceptors. Based on the 16S rRNA gene sequence, strain 106 would represent a novel genus of the previously uncultivated group (Symbiont Group I; a potentially novel family) within the Gammaproteobacteria, and 'Thioprofundum lithotrophica' gen. nov., sp. nov. is proposed. Strain 108 is a short, oval rod at any of the growth pressures. It is a facultative chemoautotroph, capable of both chemolithoautotrophic growth with $\mathrm{H}_{2}$ and $\mathrm{S}$ oxidations and organotrophic growth with complex organics or organic acids using nitrate and $\mathrm{O}_{2}$ as the electron acceptors. The chemolithoautotrophic growth is strictly piezophilic and under the organotrophic growth condition, it grows at conventional pressures $(0.1 \mathrm{MPa})$. Strain 108 is phylogenetically distinctive from any of the previously described genera of the family Rhodobacteraceae within the Alphaproteobacteria, and 'Piezobacter thermophilus' gen. nov., sp. nov. is proposed. The piezophilic cultivation technique can be a powerful tool to isolate and characterize the previously uncultivated phylotypes in the deep-sea hydrothermal vent environments.
\end{abstract}


Research on deep-sea piezophiles has half century of history since the pioneering work by Zobell \& Morita (1957). For 50 years, most of the targeted microorganisms have been heterotrophs, while very few piezophilic chemolithoautotrophs were described (Bernhardt et al., 1988; Kato, 2006; Miller et al., 1988; Park et al., 2006). Thermophilic hydrogenotrophic methanogens Methanocaldococcus jannaschii and Methanothermococcus thermolithotrophicus were isolated from deep-sea and deep subsurface environments originally by conventional, non-piezophilic cultivation techniques but were later found to be facultative piezophilic based on the hyperbaric pressure cultivation experiments (Bernhardt et al., 1988; Miller et al., 1988;). Recently, a new hydrostatic pressure cultivation technique has been developed, which has enabled cultivation of various types of deep-sea chemolithoautotrophs such as hydrogenotrophic methanogen, sulfate-reducer and $\mathrm{H}_{2^{-}}$and S-oxidizing nitrate- and $\mathrm{O}_{2}$-reducers previously isolated by non-piezophilic techniques (Takai et al., 2008a). This technique was successfully applicable even for the most hyperthermophilic microorganism, Methanopyrus kandleri, which had been also known to be quite hard to cultivate (Takai et al., 2008a). Nevertheless, all the deep-sea piezophilic chemolithoautotrophs studied so far were initially isolated by the cultures under the conventional gas pressures (up to 0.4 MPa), and none of the chemolithoautotrophs is obtained by a high-pressure culture directly from a deep-sea habitat.

Direct piezophilic enrichment from deep-sea and deep subsurface microbial communities would be advantageous to obtain the numerically predominant or the 66 functionally significant microbial populations in the in situ habitats. This is not only 
because the in situ hydrostatic pressure is a potential key physical parameter directly affecting their growth (Abe et al., 1999; Kato, 2006) but also because the pressure and temperature serve as the primary physicochemical factors preparing the thermodynamic states of energy and carbon metabolisms for their growth. That is to say, using conventional gas pressures of media, available gaseous substrates dissolved in the liquid phase of microbial medium often become much less abundant as compared to the concentrations in the in situ environments. For instances, the highest dissolved concentrations of $\mathrm{H}_{2}, \mathrm{~N}_{2}, \mathrm{CH}_{4}$ and $\mathrm{CO}_{2}$ in the deep-sea hydrothermal fluids are recorded to be up to 16, 36, 54 and $2700 \mathrm{mM}$, respectively (Charlou et al., 2002; Lupton et al., 2008; Person et al., 2005) but in the test tubes or bottles at $60{ }^{\circ} \mathrm{C}$ under a $0.2 \mathrm{MPa}$ of gas pressure, theoretically the soluble concentrations are less than $1.6,1.2,2.0$ and $23.5 \mathrm{mM}$, respectively. The different abundance of the gaseous energy and carbon sources may be a great metabolic bias for enrichment of certain populations that are less predominant in the in situ habitats but are energetically favorable in laboratory experiments. In contrast, if the piezophilic cultivation provides quite dissimilar thermodynamic states compared to those of the in situ habitats, it may lead to enrichment of previously uncultivated and unidentified microbial components of the similar environments.

In this study, we tried to cultivate $\mathrm{H}_{2^{-}}$and/or sulfur-oxidizing chemolithoautotrophs using the piezophilic cultivation technique from a black smoker chimney obtained from the TAG field in the Mid Atlantic Ridge (MAR). The TAG field is located at water depth of between 3620 and $3660 \mathrm{~m}$ and is among the world deepest hot hydrothermal systems. The $\mathrm{H}_{2^{-}}$and/or sulfur-oxidizing chemolithoautotrophs are one of the most predominant microbial populations in the global deep-sea hydrothermal 
91 been isolated as the primary components (Takai et al., 2006a; Nakagawa and Takai 92 2006; 2008). Although only one pressure-temperature (PT) condition of $50{ }^{\circ} \mathrm{C}$ and 36 93 MPa and only one medium was used in this study, two novel chemolithoautotrophic 94 bacteria were enriched and isolated by purification under different pressure conditions.

95 These piezophilic chemolithoautotrophs represented the previously uncultivated 96 phylotypes of Proteobacteria. The physiological properties of the new deep-sea 97 piezophiles were characterized under the piezophilic cultivation condition. 98 
MATERIALS AND METHODS

Sample collection and fluid chemistry: A sample from a black smoker chimney was obtained from the TAG hydrothermal field $\left(26^{\circ} 08.23 \mathrm{~N}, 44^{\circ} 49.57 \mathrm{~W}\right)$ in the Mid

102 Atlantic Ridge (MAR) at a depth of 3626 m by means of the remotely operative vehicle

103 VICTOR6000 (Ifremer) in Dive\#263 during the EXOMAR cruise performed in August 2005. This chimney was one of the numerous chimneys comprising so-called "the black smoker complex (BSC)" in the TAG field (e.g., Charlou et al., 1996). The temperature of the black smoker fluid hosted by this chimney (named as Matomo chimney) was measured to be maximally $345{ }^{\circ} \mathrm{C}$. The chimney portions were broken by a manipulator of the VICTOR6000 and directly dropped into a sample box that had been in advance

109 decontaminated and filled with the sterilized distilled water (Postec et al., 2005). The lid of the sample box was closed immediately after the sampling at the seafloor although the box did not preserve the hydrostatic pressure. However, due to the tightly sealed lid, no additional seawater mixing was expected during returning to sea surface. Immediately after the recovery of the chimney sample onboard, a relatively large

114 piece of structure, which preserved the intact structure as much as possible, was 115 subsampled into the representative microbial habitats as previously described (Takai et al., 2001; 2008b). The chimney outer surface (thickness 1 to $2 \mathrm{~mm}$ ) and chimney inside

117 part (thickness 1 to $2 \mathrm{~cm}$ ) were collected for the nucleic acid extraction, the microscopic 118 observation and the cultivation. For the subsamples of the cultivation, each of the outer 119 surface ( $2 \mathrm{~g}$ wet weight) and the inside part (40 g wet weight) was suspended in $20 \mathrm{ml}$ 120 of seawater filtered with a $0.22 \mu \mathrm{m}$ pore size filter in the presence and absence of $0.05 \%$ 121 (w/v) neutralized sodium sulfide in a $100 \mathrm{ml}$ glass bottle (Schott Glaswerke, Mainz, 
122 Germany), and then tightly sealed with a butyl rubber cap under a gas phase of $100 \% \mathrm{~N}_{2}$

123 (0.2 MPa). For the subsamples of the microscopic observation, approx. $1 \mathrm{~g}$ (wet weight)

124 of the subsample was fixed with $3 \mathrm{ml}$ of filter-sterilized seawater containing $3.7 \%(\mathrm{v} / \mathrm{v})$

125 formalin for $24 \mathrm{~h}$ and then stored at $-80{ }^{\circ} \mathrm{C}$. All the samples for cultivation were

126 transferred to our laboratory under refrigeration and were preserved at $4{ }^{\circ} \mathrm{C}$ prior to 127 experiments.

128 The hydrothermal fluid chemistry in the TAG field is already characterized in detail (Campbell et al., 1988; Charlou et al., 1996; Chiba et al., 2001). It is known that

130 the hydrothermal fluids emitting from the BSC of the TAG field have one endmember

131 fluid source (Chiba et al., 2001). The chemical composition of the endmember fluid is 132 determined and is found to be temporally stable (Campbell et al., 1988; Charlou et al., 133 1996; Chiba et al., 2001).

134 Total direct cell counts: Microbial community densities in the chimney subsamples were determined by 4',6-diamidino-2-phenylindole (DAPI)-staining direct count. The frozen formalin-fixed chimney subsample was thawed, and then vigorously 137 suspended with a vortex mixer. After $5 \mathrm{~min}$ of static state, $0.5 \mathrm{ml}$ of formalin-fixed 138 supernatant was added to $0.5 \mathrm{ml}$ of filter-sterilized phosphate-buffered saline (PBS, $\mathrm{pH}$ 139 7.2) containing DAPI $(10 \mu \mathrm{g} / \mathrm{ml})$, and incubated at room temperature for $30 \mathrm{~min}$. After 140 the mixture was filtered, each filter was rinsed twice with $2 \mathrm{ml}$ of filter-sterilized PBS.

141 The filters were examined under epifluorescence using a phase-contrast Olympus BX51 142 microscope with the Olympus DP71 digital camera system. An average total cell count 143 was obtained from more than 100 microscopic fields from three separate filters.

144 Liquid serial dilution cultures: To estimate the abundance of culturable 145 microorganisms (viable counts) represented by a variety of physiological and metabolic 
146 characteristics, a series of serial dilution cultures were done from the chimney

147 subsamples under the various cultivation conditions, which were in a same manner as 148 previously described (e.g., Takai et al., 2008b). Since the detail methods and results will

149 be described elsewhere, only the media and culture conditions that gave positive

150 cultivation results were described (Table 1). For anaerobic, heterotrophic

151 sulfur-reducing thermophiles such as members of Thermococcales and Thermotogales,

152 MJYPS medium (Takai et al., 2000) was used (Table 1). For hydrogen- and/or

153 sulfur-oxidizing chemolithoautotrophs, such as members of Aquificales,

154 Gammaproteobacteria and Epsilonproteobacteria, MMJHS medium (Takai et al. 2003)

155 was used (Table 1). For anaerobic dissimilatory Fe(III)- and/or sulfate-reducers, such as

156 members of Archaeoglobales, Deferribacteres, Thermodesulfobacteria and

157 Deltaproteobacteria, a MMJHFe medium (Takai et al. 2008b) was used (Table 1).

158 A serial dilution culture using a piezophilic cultivation technique (Takai et al., 159 2008a) was also performed with the chimney surface sample at $50{ }^{\circ} \mathrm{C}$ and at $36 \mathrm{MPa}$

160 (Table 1). The detail procedure is described below.

161 The microbial growth was identified by turbidity and/or microscopic observation

162 for maximally 2 months. The microorganism present in the most diluted series of the

163 medium at each temperature was isolated by the subsequent extinction-dilution method

164 (Takai and Horikoshi, 2000). The partial sequences of the 16S rRNA genes (approx.

$165700-1000 \mathrm{bp}$ ) of the isolates were determined as described elsewhere (Takai et al..

166 2004).

167 Enrichment and purification with piezophilic cultivation techniques: The

168 chimney surface slurry preserved in the absence of sodium sulfide was inoculated into

169 the test tubes containing MMJHS medium (Takai et al., 2003) under a gas phase of $80 \%$ 
$170 \mathrm{H}_{2}+20 \% \mathrm{CO}_{2}(0.2 \mathrm{MPa})$ with every $1 / 5$ dilution. A $1 \mathrm{ml}$ portion of the inoculated

171 culture was taken from each of the serial dilution of test tubes into a piezophilic 172 cultivation syringe and then, a $250 \mu \mathrm{l}$ of $100 \% \mathrm{H}_{2}$ was added to the syringe 173 (corresponding to approx. $10 \mathrm{mM}$ of soluble $\mathrm{H}_{2}$ and $30 \mathrm{mM}$ of $\Sigma \mathrm{CO}_{2}$ under the 174 piezophilic condition) (Takai et al., 2008a). The syringe was sealed by a needle sticking 175 into a butyl rubber stopper (Takai et al., 2008a). Finally, the pressure vessels containing 176 the cultivation syringes were compressed by a hydraulic pomp at $36 \mathrm{MPa}$ and incubated 177 at $50{ }^{\circ} \mathrm{C}$ for two weeks. The serial dilution culture under the piezophilic condition was 178 conducted twice.

179 After two weeks of incubation, the possible enrichment was examined by a 180 microscopic observation. Up to a certain dilution of culture, two morphotypes of 181 microorganisms were identified; one was a motile, thin, long spiral cell and the other was a non-motile, short, oval rod. The short, oval rods were also observed in two more dilution steps of culture than the one containing two morphotypes. Thus, the highest dilution of culture of oval rods was further conducted to the extinction-dilution culture

185 for the purification under the same condition. For the purification of long spiral cells,

186 the highest dilution of culture including the long spiral and short oval cells were 187 inoculated into a serial dilution of MMJHS medium under a gas phase of $80 \% \mathrm{H}_{2}+$ $18820 \% \mathrm{CO}_{2}(0.2 \mathrm{MPa})$ and incubated under the non-piezophilic condition at $50{ }^{\circ} \mathrm{C}$. Under 189 the non-piezophilic culture condition, only the long spiral cells were grown. The highest 190 dilution obtained from the non-piezophilic cultivation was again applied to the serial 191 dilution cultivation under the piezophilic cultivation condition (36 MPa). This 192 procedure provided only the growth of long spiral cells under the high pressure. Thus, 193 the extinction-dilution purification of this morphotype was conducted by the repeated 
cultivation under every piezophilic and non-piezophilic condition.

Finally, two morphotypes were isolated and were designated as strain 106 (long spiral cell) and strain 108 (short oval rod), respectively. The purity was confirmed

197 routinely by microscopic examination and by repeated partial sequencing of the $16 \mathrm{~S}$ 198 rRNA gene using several PCR primers.

199 Morphology: Cells were routinely observed under a phase-contrast Olympus 200 BX51 microscope with the Olympus DP71 digital camera system. Transmission 201 electron microscopy of negatively stained cells was carried out as described by Zillig et al. (1990). Cells grown in MMJHS medium under the optimal hydrostatic pressures (strains 106 and 108) or the conventional gas pressure (0.2 $\mathrm{MPa}$ ) (strain 106) were negatively stained with $2 \%(\mathrm{w} / \mathrm{v})$ uranyl acetate and observed under a JEOL JEM-1210 electron microscope at an accelerating voltage of $80 \mathrm{kV}$.

Growth characteristics: Both strains were routinely cultivated at $16 \mathrm{MPa}$ (for strain 106) or $36 \mathrm{MPa}$ (for strain 108) in Piezo-MMJHS medium, which containing 10 $\mathrm{mM}$ of dissolved $\mathrm{H}_{2}$ and $30 \mathrm{mM}$ of $\Sigma \mathrm{CO}_{2}$ in $1 \mathrm{ml}$ of modified MMJHS medium (Takai et al., 2003) in a $5 \mathrm{ml}$ of piezophilic cultivation syringe. The original MMJHS medium contained $10 \mathrm{mM}$ of sodium nitrate but the modified MMJHS medium including $20 \mathrm{mM}$ of sodium nitrate was used for the subsequent experiments. The $\mathrm{pH}$ of the medium was routinely checked before, during and after the growth at a room temperature. The initial $\mathrm{pH}$ of Piezo-MMJHS medium was adjusted to 6.5.

214 Growth was measured by direct cell counting after staining with DAPI using a

215 phase-contrast Olympus BX51 microscope. All experiments described below were 216 conducted in duplicate. To test the effects of hydrostatic pressure and temperature on 217 growth, cultures with Piezo-MMJHS medium were incubated at a varying hydrostatic 
218 pressure of 0.2 (non-piezophilic condition), 5, 16, 36, 50 or $65 \mathrm{MPa}$ at $50{ }^{\circ} \mathrm{C}$ and at 219 every $5{ }^{\circ} \mathrm{C}$ between 25 and $60{ }^{\circ} \mathrm{C}$ at the optimal pressures. For testing the effect of pH 220 on growth, the $\mathrm{pH}$ of Piezo-MMJHS medium was adjusted to lower $\mathrm{pH}$ than $\mathrm{pH} 6.5$ 221 with decreasing concentration of sodium bicarbonate and by adding $\mathrm{HCl}$ in MMJHS 222 medium, while was adjusted to higher $\mathrm{pH}$ than 6.5 with increasing concentration of 223 sodium bicarbonate and by adding $\mathrm{NaOH}$ in MMJHS medium. The growth was conducted at $50{ }^{\circ} \mathrm{C}$ and the optimal pressures. The effect of $\mathrm{NaCl}$ on growth was test in Piezo-MMJHS medium by varying a $\mathrm{NaCl}$ concentration in MMJHS medium.

The potential nutrients required for growth such as selenite, tungstate and vitamins were examined with Piezo-MMJHS medium under an optimal pressure with and without the specified nutrients. The nitrogen source $\left(\mathrm{NH}_{4} \mathrm{Cl}, \mathrm{NaNO}_{2}, \mathrm{~N}_{2}, \mathrm{NaNO}_{3}\right.$ and yeast extract) for growth was also examined with Piezo-MMJHS medium including none of the nitrogen sources under an optimum pressure. Antibiotics susceptibility was tested with Piezo-MMJHS medium at an optimal pressure by using a $50 \mu \mathrm{g} / \mathrm{ml}$ of ampicilin, kanamycin, chloramphenicol, streptomycin or vancomycin.

234 for autotrophic growth of both strains, each of the $\mathrm{H}_{2}(10 \mathrm{mM})$, elemental sulfur (3\%, $235 \mathrm{w} / \mathrm{v})$, thiosulfate $(10 \mathrm{mM})$, sulfide $(1.25 \mathrm{mM})$, cystein- $\mathrm{HCl}(2.5 \mathrm{mM})$, tetrathionate $(5$ $\mathrm{mM})$, and sulfite $(2.5 \mathrm{mM})$ was tested instead of a combination of $\mathrm{H}_{2}$, elemental sulfur and thiosulfate as a sole electron donor in Piezo-MMJHS medium (nitrate as a sole electron acceptor) at $50{ }^{\circ} \mathrm{C}$ and an optimal pressure. In contrast, to examine potential electron acceptors for autotrophic growth of both strains, each of nitrate $(20 \mathrm{mM})$ and $\mathrm{O}_{2}(0.04,0.12,0.4,1.2,2$ or $4 \mathrm{mM})$ was tested instead of a combination of nitrate, 241 elemental sulfur and thiosulfate as a sole electron acceptor in MMJHS medium 
242 (thiosulfate as a sole electron donor) at $50{ }^{\circ} \mathrm{C}$ and an optimal pressure. If $\mathrm{H}_{2}(10 \mathrm{mM})$

243 was used as a sole electron donor, each of elemental sulfur $(3 \% \mathrm{w} / \mathrm{v})$, thiosulfate $(10$

$244 \mathrm{mM})$, sulfite $(2.5 \mathrm{mM})$ and ferrihydrite $(5 \mathrm{mM})$ was also tested.

245 Heterotrophic growth was tested for both strains using Piezo-MMJHS medium 246 including yeast extract $(0.1 \%, \mathrm{w} / \mathrm{v})$, tryptone $(0.1 \%, \mathrm{w} / \mathrm{v})$, Casamino acid $(0.1 \%$, w/v),

247 formate $(5 \mathrm{mM})$, acetate $(5 \mathrm{mM})$ or pyruvate $(5 \mathrm{mM})$ instead of $30 \mathrm{mM}$ of $\Sigma \mathrm{CO}_{2}$ at 50

$248{ }^{\circ} \mathrm{C}$ and under an optimum pressure. The $\mathrm{pH}$ of the media was adjusted at 6.5 in advance.

249 In addition, organotrophic growth was tested using Piezo-MMJHS medium including 250 yeast extract $(0.1 \%, w / v)$, tryptone $(0.1 \%, w / v)$, Casamino acid $(0.1 \%, w / v)$, formate $(5$ $251 \mathrm{mM})$, acetate $(5 \mathrm{mM})$ or pyruvate $(5 \mathrm{mM})$ at $\mathrm{pH} 6.5$ instead of $\mathrm{H}_{2}$, thiosulfate, elemental 252 sulfur and $30 \mathrm{mM}$ of $\Sigma \mathrm{CO}_{2}$ at $50{ }^{\circ} \mathrm{C}$ and under an optimal pressure.

253 Time course of oxidations of $\mathrm{H}_{2}$ (strain 108) and thiosulfate (strains 106 and 108) 254 by nitrate-reduction and concomitant growth of both strains were examined with 255 Piezo-MMJHS medium as $\mathrm{H}_{2}$ or thiosulfate as a sole electron donor, of which all the 256 sulfate salts were replaced by the chloride salts, at $50{ }^{\circ} \mathrm{C}$ and under an optimal pressure. 257 The concentrations of nitrate, thiosulfate and sulfate were analyzed by ion 258 chromatography using a Shim-pack IC column (Shimadzu, Kyoto, Japan) and the 259 concentration of $\mathrm{H}_{2}, \mathrm{~N}_{2} \mathrm{O}$ and $\mathrm{N}_{2}$ was measured by a gas chromatography Micro GC 260 CP2002 (GL Sciences, Tokyo, Japan) with a thermal conductivity detector. Nessler's reagent was employed to monitor the production of ammonium ion. using cells autotrophically grown at $50{ }^{\circ} \mathrm{C}$ under the optimal pressure and the 264 non-piezophilic condition for strain 106, and using cells harvested from the piezophilic 265 autotrophic condition (at $50{ }^{\circ} \mathrm{C}$ and $36 \mathrm{MPa}$ ) and the non-piezophilic organotrophic 
condition (at $50{ }^{\circ} \mathrm{C}$ and $0.1 \mathrm{MPa}$ ) for strain 108 . Lyophilized cells (30 mg) were placed

267 in a Teflon-lined, screw-capped tube containing $1 \mathrm{ml}$ of anhydrous methanolic $\mathrm{HCl}$ and

268 heated at $100{ }^{\circ} \mathrm{C}$ for $3 \mathrm{~h}$. The resulting fatty acid methyl esters (FAMEs) were extracted

269 twice with n-hexane and concentrated under a stream of nitrogen gas. The FAMEs were

270 analyzed using a gas chromatography-mass spectrometer (Xcalibur for Trace DSQ,

271 Thermoelectron).

272 Nucleic acid analyses: DNA was prepared as described by Marmur \& Doty

273 (1962). The G+C content of DNA was determined by direct analysis of 274 deoxyribonucleotides on HPLC (Tamaoka and Komagata, 1984). The 16S rRNA gene 275 was amplified by PCR using Bac 27F and 1492R primers (DeLong, 1992; Lane, 1985).

276 The nearly complete sequences of the16S rRNA genes from both strains were directly 277 sequenced by both strands using the dideoxynucleotide chain termination method with a DNA sequencer Model 3100 (Perkin Elmer/Applied Biosystems Co., Foster City, CA, USA). The nearly complete sequences were manually aligned to the representative sequences according to the secondary structures using ARB (Ludwig et al., 2004). Phylogenetic analyses were restricted to unambiguously aligned nucleotide positions.

282 Evolutionary distance matrix analysis (using the Jukes \& Cantor correlation method)

283 and neighbor-joining analysis were performed using PHYLIP package 284 (http://evolution.genetics.washington.edu/phylip.html). Bootstrap analysis was 285 performed to provide confidence estimates for phylogenetic tree topologies.

286 The 16S rRNA gene sequences of strains 106 and 108 were deposited in the 287 DDBJ/EMBL/GenBank nucleotide sequence databases with the accession numbers 288 AB468957 and AB468958, respectively.

289 Whole cell fluorescence in situ hybridization (FISH) analysis: The whole cell 
290 FISH analysis was conducted to estimate the cellular abundance of strains 106 and 108

291 and their relatives in the in situ chimney habitat by using the 16S rRNA gene sequences.

292 The targeted microbial populations were the whole microbial cells (DAPI-stained cell

293 fraction and both bacterial- and archaeal-probes-binding cell fraction), the strain 106

294 cells (a specific probe-binding cell fraction) and the strain 108 cells (a specific

295 probe-binding fraction), respectively. The EUB338 (Stahl and Amann, 1991) and the

296 ARC915 (Amann et al., 1990) probes were used for the detection of both bacterial and

297 archaeal populations. The ribosomal RNA-targeted oligonucleotide probes specifically

298 binding to the $16 \mathrm{~S}$ rRNAs of strains 106 and 108, respectively, were designed using

299 ARB (Ludwig et al., 2004) based on the multiply aligned sequences including those of

300 strains 106 and 108. Among several potential sites for the probes, the probes designated

301 as TF1110 (5'-CTCCATCTCTGGAGCCTTCC-3') and PB1001

302 (5'-TGGTAACTGAGGGCGTGGGT-3') were finally chosen through the sequence

303 specificity analysis using the BLAST program to all the nucleic acid sequences in the

304 DDBJ/EMBL/GenBank nucleotide sequence databases. In the in silico analysis, the

305 TF1110 probe was found to have at least three bases of mismatch with any other 16S

306 rRNA sequences and the PB1001 probe also had more than three bases of mismatch

307 with any other 16S rRNA sequences except for the 16S rRNAs of Methanobrevibacter

308 spp. (one mismatch).

309 The whole cell FISH experiments were performed as previously described

310 (Sekiguchi et al., 1999). The frozen formalin-fixed chimney subsample was thawed, and

311 then vigorously suspended with a vortex mixer. After 5 min of static state, $0.5 \mathrm{ml}$ of

312 formalin-fixed supernatant was centrifuged at a $15000 \mathrm{rpm}$ at $4{ }^{\circ} \mathrm{C}$ for $30 \mathrm{~min}$. After

313 washing with a $0.5 \mathrm{ml}$ of PBS (pH 7.2) twice, the microbial cells were immobilized on a 
314 positive charged glass slide. Hybridization was performed with both the

315 Alexa488-labeled EUB338 and the ARC915 probes and with each of the Cy3-labeled

316 specific probes TF1110 and PB1001 at $46{ }^{\circ} \mathrm{C}$ for $3 \mathrm{~h}$. The hybridization stringency was

317 adjusted with varying concentrations of formamide in the hybridization buffer (30\% for

318 the ARC915, TF1110 and PB1001 probes, and 10\% for the EUB338 probe). After the

319 hybridization and the washing, the cells were stained with PBS (pH 7.2) containing

320 DAPI $(10 \mu \mathrm{g} / \mathrm{ml})$ for $30 \mathrm{~min}$. The slide was examined under an Olympus BX51

321 epifluorescence microscopy with the Olympus DP71 digital camera system. The cells of

322 E. coli strain K12 and the other strain cells of strains 106 and 108 were used as the

323 negative controls. An average of the ratio of probe-hybridized cells to the DAPI-stained

324 cells was determined from more than 100 microscopic fields. 


\section{RESULTS AND DISCUSSION}

327 Chimney habitats and total, viable and FISH cell counts: At the present, it is still 328 very difficult to determine directly the physical and chemical conditions of the 329 microbial habitats in the chimney structure by using some of the in situ hardware such 330 as temperature-, $\mathrm{pH}-$ and other chemical-sensors at the deep seafloor. Thus, the potential chemical conditions for a given temperature range of chimney habitat have been often extrapolated by the mixing between the hot endmember hydrothermal fluid and the cold ambient seawater (McCollom and Shock, 1997; Shock and Holland, 2004; Tivey, 334 2004).

According to the chemical composition of the endmember hydrothermal fluid in the BSC of the TAG field already reported (Campbell et al., 1988; Charlou et al., 1996;

337 Chiba et al., 2001), the potential concentration ranges of gaseous energy and carbon substrates in the chimney habitats were estimated. If the microbially habitable temperature range was assumed to be up to $\sim 130{ }^{\circ} \mathrm{C}$ that could be brought by a simple mixing of approx. 1:2 ratio between the hydrothermal fluid and the seawater in the case

341 of the TAG field, the available concentrations of dissolved $\mathrm{H}_{2}, \mathrm{~N}_{2}, \mathrm{CO}_{2}, \mathrm{CH}_{4}$ and $\mathrm{H}_{2} \mathrm{~S}$ 342 are estimated to be up to $0.12,0.3,3.4,0.05$ and $2.3 \mathrm{mM}$, respectively, based on the 343 highest values reported by Campbell et al. (1988) and Charlou et al. (1996). The total 344 dissolved concentrations of $\mathrm{H}_{2}, \Sigma \mathrm{CO}_{2}$ and reduced sulfur compounds were about 10, 30 and $10 \mathrm{mM}$ in Piezo-MMJHS medium and $<1.3,30$ and $10 \mathrm{mM}$ in non-piezophilic MMJHS medium at $50{ }^{\circ} \mathrm{C}$, respectively. Thus, the enrichment by using Piezo-MMJHS

347 medium might provide a larger chemical dissimilarity than that under the 348 non-piezophilic condition, particularly in dissolved $\mathrm{H}_{2}$ concentration, between the in 
349 situ habitats and the laboratory experiments. The dissolved $\mathrm{H}_{2}$ concentration and 350 hydrostatic pressure could be significantly different under piezophilic and 351 non-piezophilic enrichment culture conditions.

352 The total cell counts in the chimney inside and surface habitats were $3.2 \times 10^{5} \pm$ $3537.2 \times 10^{4}$ and $9.6 \times 10^{6} \pm 4.0 \times 10^{5}$ cell/g (wet weight), respectively. These total cell 354 counts were very comparable to those in other black smoker chimneys studied so far in 355 different deep-sea hydrothermal systems (e.g., Takai et al., 2008b). In addition to the total cell counts in the chimney habitats, the viable counts of the representative cultivated populations in the habitats were also determined under the conventional cultivation conditions. From the chimney surface habitat, members of the genera Thermococcus, Deferribacter, Persephonella and Sulfurimonas were cultivated as the

360 predominant populations. The viable cell counts of these members were $10^{6}-10^{7}$ cells/g for Thermococcus, $10^{3}-10^{4}$ cells/g for Deferribacter, $10^{5}-10^{6}$ cells/g for Persephonella, and $10^{5}-10^{6}$ cells/g for Sulfurimonas, respectively. Based on these viable cell counts by the serial dilution cultivation experiments under the non-piezophilic condition, the

364 predominant $\mathrm{H}_{2}$ and/or S-oxidizing chemolithoautotrophic members in the TAG black smoker chimney surface were represented by Persephonella spp. within the Aquificae and Sulfurimonas spp. within the Epsilonproteobacteria, which has been commonly observed in other chimney habitats of the different hydrothermal systems (e.g., Takai et al., 2008b).

On the other hand, based on the estimation of the viable cell counts under the 370 piezophilic cultivation condition, strains 106 and 108 represented $0.6-3.0 \times 10^{3}$ cells/g 371 and $1.5-7.5 \times 10^{4}$ cells/g, respectively. These population sizes were lower than that of 372 the Persephonella members growing at the same temperature under the non-piezophilic 
373 cultivation condition, but represented $0.01-0.3 \%$ (for strain 106) and $0.2-7.5 \%$ (for

374 strain 108) of the sum of viable cell counts in the chimney surface habitat. In the highest

375 dilution culture of a serial dilution experiment using the non-piezophilic MMJHS

376 medium at $50{ }^{\circ} \mathrm{C}$, a minor but certain proportion of thin, long spiral cells were observed

377 together with abundant, short rod cells of the Persephonella members. This morphotype

378 of microorganism was successfully cultivated and isolated from the highest dilution of

379 culture using Piezo-MMJHS medium. The partial 16S rRNA gene sequence of the

380 isolate was $99.8 \%$ identical to that of strain 106. Thus, the viable cell count of strain 106

381 under the non-piezophilic cultivation condition was considered to be $10^{5}-10^{6}$ cells/g,

382 which was equivalent to that of the Persephonella members and $1-50 \%$ of the sum of

383 viable cell counts. These results suggested that both strains 106 and 108 were novel

384 microbial components previously uncultivated from other deep-sea hydrothermal

385 systems but potentially represented the functionally significant $\mathrm{H}_{2}$ - and/or S-oxidizing

386 chemolithoautotophic components in the chimney structure of the TAG field.

387 The estimation of the cellular abundance of strains 106 and 108 by the FISH

388 analysis indicated that both strains can be not only the functionally and metabolically

389 significant members in the viable microbial populations but also the numerically

390 considerable components in the total cell count of the microbial community. The

391 proportion of strains 106 and 108 cells in the total cell counts determined by the

392 DAPI-staining and the hybridization with either the bacterial or the archaeal probe

393 (EUB338 or ARC915) was 3.4 and $3.6 \%$ for strain 106 and 1.1 and $1.2 \%$ for strain 108,

394 respectively. These results were not so inconsistent with the proportion of viable

395 populations of strains 106 and 108 in the sum of viable cell counts determined by the

396 cultivation experiments. It seems likely, therefore, that the piezophilic cultivation 
technique is a powerful experimental scheme to explore the previously uncultivated but

ecophysiologically significant chemolithoautotrophs in the deep-sea hydrothermal environments.

Morphological, physiological and metabolic properties of strain 106: Cells of strain 106 were motile (not all the cells but some), long, thin spiral and approximately 6-20 $\mu \mathrm{m}$ long and 0.4-0.6 $\mu \mathrm{m}$ wide, with a polar flagellum under the piezophilic cultivation condition (Fig. 1a). Under the conventional gas pressure condition (0.2 MPa), however, most of the cells became shorter (up to $4 \mu \mathrm{m}$ long) with motility (Fig. 1b). As compared to other deep-sea chemolithoautotrophs having similar growth temperature ranges with the Aquificae and Epsilonproteobacteria, strain 106 was morphologically novel.

Strain 106 autotrophically grew at a temperature range between 30 and $55{ }^{\circ} \mathrm{C}$ (optimally $50{ }^{\circ} \mathrm{C}$ ) (Fig. 2a), at a pH range between 5.8 and 7.6 (optimally $\mathrm{pH} 7.0$ ) (Fig. 2b) and at a $\mathrm{NaCl}$ range from 1.2 to $4.2(\%$; w/v) (optimally 3\%) (Fig. 2c) under the piezophilic cultivation condition. In addition, the growth of strain 106 was observed at a hydrostatic pressure range between 0.2 and $36 \mathrm{MPa}$, and the highest growth rate was

413 identified at $16 \mathrm{MPa}$ (Fig. 3). Thus, strain 106 was piezophilic but not a strict 414 piezophile.

The ability of strain 106 to utilize various electron donors, electron acceptors, and carbon sources was investigated using a range of substrates under the piezophilic and non-piezophilic conditions (Table 2). Strain 106 grew chemolithoautotrophically with 418 elemental sulfur, thiosulfate, tetrathionate or sulfite as a sole electron donor and with 419 nitrate or $\mathrm{O}_{2}$ as a sole electron donor (Table 2). Organic compounds served as neither energy nor carbon sources. Strain 106 was found to be a strict chemolithoautotroph. In 
421 addition, strain 106 was able to utilize $\mathrm{O}_{2}$ as the electron acceptor but its $\mathrm{O}_{2}$ utilization 422 represented the microaerophilic mode (up to $0.4 \mathrm{mM}$ of dissolved $\mathrm{O}_{2}$ concentration or $4235 \%$ of $\mathrm{O}_{2}$ partial pressure) (Table 2). Strain 106 utilized nitrate, ammonium and yeast 424 extract as a nitrogen source. Molecular nitrogen $\left(\mathrm{N}_{2}\right)$ could also support the growth as a 425 sole nitrogen source, suggesting the possible $\mathrm{N}_{2}$ fixation, although the existence of 426 genetic components of $\mathrm{N}_{2}$ fixation enzymes (nif genes) and the ${ }^{15} \mathrm{~N}_{2}$ incorporation into 427 the cellular nitrogens were not experimentally examined. Selenium, tungsten and vitamins were not required for the growth.

A time course of oxidation of thiosulfate by nitrate-reduction and concomitant growth under the piezophilic condition were characterized (Fig. 4a). During the growth, thiosulfate and nitrate were consumed, and sulfate, $\mathrm{N}_{2}$ and $\mathrm{N}_{2} \mathrm{O}$ were accumulated (Fig. 4a). None of the other potentially intermediate products such as sulfite and nitrite from the thiosulfate-oxidation and the nitrate-reduction was detected (Fig. 4a). The consumption of thiosulfate and nitrate was stoichiometrically equivalent to the accumulation of sulfate and gaseous nitrogen compounds (Fig. 4a). These results clearly demonstrated that strain 106 was a strictly chemolithoautotrophic, facultatively anaerobic piezophile oxidizing the reduced sulfur compounds to sulfate by $\mathrm{O}_{2^{-}}$or nitrate-reduction.

Strain 106 was found to be sensitive to a variety of antibiotics, including 440 chloramphenicol $\left(50 \mu \mathrm{g} \mathrm{ml}^{-1}\right)$, streptomycin $\left(50 \mu \mathrm{g} \mathrm{ml} l^{-1}\right), \operatorname{kanamycin}\left(50 \mu \mathrm{g} \mathrm{ml}^{-1}\right)$, 441 ampicillin $\left(50 \mu \mathrm{g} \mathrm{ml}^{-1}\right)$ and vancomycin $\left(50 \mu \mathrm{g} \mathrm{ml}^{-1}\right)$.

443 strain 108 were non-motile, short, oval and approximately $1-1.5 \mu \mathrm{m}$ long and $0.6-0.7$ $444 \mu \mathrm{m}$ wide under any of the cultivation conditions (Fig. 1c). No flagellum was observed 
(Fig. 1c).

Strain 108 autotrophically grew at a temperature range between 30 and $55{ }^{\circ} \mathrm{C}$

447 (optimally $50{ }^{\circ} \mathrm{C}$ ) (Fig. 2a), at a pH range between 5.5 and 7.5 (optimally pH 6.5-7.0)

448 (Fig. 2b) and at a $\mathrm{NaCl}$ range from 1.2 to 5.4 (\%; w/v) (optimally 2\%) (Fig. 2c) under

449 the piezophilic cultivation condition. The autotrophic growth of strain 108 was strictly

450 piezophilic and was observed at a hydrostatic pressure range between 16 and $65 \mathrm{MPa}$,

451 and the highest growth rate was obtained at $36 \mathrm{MPa}$ (Fig. 3). Although the piezophilic

452 response in the organotrophic growth of strain 108 was not fully determined, strain 108

453 was able to grow with the organic substrates under the conventional non-piezophilic

454 condition (0.1 MPa of Air). The optimal hydrostatic pressure for the autotrophic growth

455 was equivalent to the in situ pressure of the seafloor at which the TAG hydrothermal

456 field is located. It has been reported that many deep-sea hydrothermal vent

457 hyperthermophilic heterotrophs demonstrate the greater hydrostatic pressure optima for

458 growth than the pressure corresponding to their seafloor habitats (Deming and Baross,

459 1993). The difference in hydrostatic pressure at which the hyperthermophiles grow

460 favorably in the laboratory experiments and naturally in the in situ seafloor may point to

461 the possible existence of deep, hot subseafloor biosphere beneath the hydrothermal

462 active seafloor (Deming and Baross, 1993). Unlike many hyperthermophilic

463 heterotrophs such as Thermococales members, the growth pressure optima of strains

464106 and 108 matched the water depth range of many seafloor hydrothermal systems in

465 the present Earth $(>1000-<4000 \mathrm{~m})$. Thus, these strains may represent the indigenous,

466 functionally active microbial components thriving at the hydrothermally associated

467 habitats at around the seafloor.

468 The energy and carbon metabolisms of strain 108 were quite different from those 
of strain 106 (Table 2). It was capable of both chemolithoautotrophic and organotrophic growth (Table 2). The possible inorganic electron donor to support the growth was $\mathrm{H}_{2}$,

471 elemental sulfur, thiosulfate, cystein- $\mathrm{HCl}$, tetrathionate or sulfite, and various organic 472 compounds such as yeast extract, tryptone, acetate and pyruvate also served as the 473 energy sources (Table 2). All these organic compounds and Casamino acid were utilized 474 as the carbon source instead of the inorganic carbons. Both the chemolithoautotrophic 475 and organotrophic growth were based on the electron acceptors of nitrate and $\mathrm{O}_{2}$ (Table 2), and the $\mathrm{O}_{2}$-dependent growth was fully aerobic (Table 2). These results demonstrate that strain 108 is a piezophilic, facultatively anaerobic and chemolithoautotrophic, thermophile. Strain 108 utilized nitrate and ammonium as a nitrogen source. Similarly as strain 106, molecular nitrogen $\left(\mathrm{N}_{2}\right)$ could be utilized as a sole nitrogen source 480 although the existence of genetic components of $\mathrm{N}_{2}$ fixation enzymes (nif genes) and the ${ }^{15} \mathrm{~N}_{2}$ incorporation into the cellular nitrogens were not experimentally checked. Selenium, tungsten and vitamins were not required for the growth.

A time course of oxidation of either $\mathrm{H}_{2}$ or thiosulfate by nitrate-reduction and concomitant growth under the piezophilic condition were characterized (Figs. $4 \mathrm{~b}$ and 4c). During the growth, either $\mathrm{H}_{2}$ or thiosulfate and nitrate were consumed, and either $\mathrm{H}_{2} \mathrm{O}$ (not identified) or sulfate and $\mathrm{N}_{2} \mathrm{O}$ were accumulated (Figs. $4 \mathrm{~b}$ and $4 \mathrm{c}$ ). The consumptions of thiosulfate and nitrate were stoichiometrically equivalent to the accumulation of sulfate and $\mathrm{N}_{2} \mathrm{O}$ during the thiosulfate-dependent growth (Fig. 4c), while $\mathrm{H}_{2}$ consumption was too much as expected by the extent of nitrate-reduction (Fig. 4b). As mentioned in the previous study for development of this piezophilic cultivation 491 technique (Takai et al., 2008a), it is inevitable that a certain proportion of $\mathrm{H}_{2}$ gas leaks 492 from the piezophilic cultivation syringe during the experiment. Probably, the excess 
amount of $\mathrm{H}_{2}$ consumption observed was due to the excess amount of $\mathrm{H}_{2}$ leak as compared to the control experiment without the microbial inoculum. These results demonstrated that strain 108 was a piezophilic, $\mathrm{N}_{2} \mathrm{O}$-producing $\mathrm{H}_{2^{-}}$and S-oxidizer under the chemolithoautotrophic growth condition.

Strain 108 was also sensitive to a variety of antibiotics, including chloramphenicol $\left(50 \mu \mathrm{g} \mathrm{ml}^{-1}\right)$, streptomycin $\left(50 \mu \mathrm{g} \mathrm{ml}^{-1}\right)$, kanamycin $\left(50 \mu \mathrm{g} \mathrm{ml}^{-1}\right)$, ampicillin $\left(50 \mu \mathrm{g} \mathrm{ml}^{-1}\right)$ and vancomycin $\left(50 \mu \mathrm{g} \mathrm{ml}^{-1}\right)$.

Cellular fatty acid composition: Cellular fatty acid compositions of strains 106 and 108 grown at the optimal pressures and at the conventional pressures are shown in Table 3. Each of the fatty acid components was typical as the components observed in the Proteobacteria except for small amounts of odds number of carbon chains $\left(\mathrm{C}_{15}\right.$ and $\mathrm{C}_{17}$ ) found in strain 106 (Table 3). The different patterns in the compositions of both strains were notable between the cells grown under the piezophilic and non-piezophilic conditions (Table 3). Since the first discovery (DeLong and Yayanos, 1985; 1986), it has been well known that the fatty acid compositions of many deep-sea piezophilic bacteria vary as a function of pressure. At the present, it has become evident that the pressure-controlled variability in the fatty acid compositions of the deep-sea piezophilic bacteria is not simply generalized (e.g., Mangelsdorf et al., 2005). Nevertheless, an increasing ratio of total unsaturated fatty acids to saturated fatty acids with an increasing hydrostatic pressure initially suggested by DeLong and Yayanos (1985; 1986) still works as a very practical principle in most cases. Indeed, the pressure-induced enrichment of the unsaturated fatty acids was identified in our new piezophilic, chemolithoautotrophic bacteria (Table 3). This is the first evidence showing that the pressure-induced enrichment of the cellular unsaturated fatty acids was applicable not 
only to the deep-sea heterotrophic bacteria but also to the deep-sea piezophilic, 518 chemolithoautotrophic bacteria.

519 Genetic characteristics: The $\mathrm{G}+\mathrm{C}$ contents of the genomic DNA were found to 520 be $65.7 \mathrm{~mol} \%$ for strain 106 and $66.2 \mathrm{~mol} \%$ for strain 108, respectively.

521 The nearly complete $16 \mathrm{~S}$ rRNA gene sequences of both strains (1487 bp for strain

522106 and 1302 bp for strain 108) were determined and applied to the sequence similarity analysis. The 16S rRNA gene sequence of strain 106 was the most closely related to the sequences of a deep-sea hydrothermal vent gastropod Alviniconcha hessleri gill endosymbiont (94.0\%) obtained from the Mariana Trough deep-sea hydrothermal system (Suzuki et al., 2005), while it was distantly related with any of the previously described gamma-proteobacterial species of which the most similar sequence was that of Sulfurivirga caldicuralii (90.5\%) (Takai et al., 2006b). The 16S rRNA gene sequence of strain 108 was distantly related to any of the sequences phylogenetically affiliated with the family Rhodobacteraceae within the Alphaproteobacteria. The most similar sequence of the previously described species was that of Paracoccus koreensis (93.9\%) (La et al., 2005). These results strongly suggested that the new thermophilic piezophiles were previously uncultivated phylotypes within the Proteobacteria.

To characterize the phylogenetic relationship between the new isolates and the previously described species within the Alphaproteobacteria and Gammaproteobacteria, the phylogenetic tree was reconstructed together with the representative environmental clones and species reported so far (Fig. 5). The tree indicated that strain 106 was

538 phylogenetically associated with many of the thioautotrophic gamma-proteobacterial endosymbionts in the deep-sea chemosynthetic animals, which are tentatively classified

540 into the Symbiont Group I including the endosymbionts in tubeworms and snails and 
541 the Symbiont Group II consisting of the thioautotrophic endosymbionts of mussels and

542 clams (Fig. 5). On the other hand, strain 108 was firmly affiliated within the family

543 Rhodobacteraceae of the Alphaproteobacteria (Fig. 5). However, strain 108 was

544 phylogenetically distinctive from any of the previously described genera of the family

545 (Fig. 5). Strain 108 was the first member of the Rhodobacteraceae and the first 546 thermophilic and chemolithoautotrophic alpha-proteobacterium isolated from the 547 deep-sea hydrothermal vent environments (e.g., Nakagawa and Takai, 2006; 2008), and 548 even represented a novel alpha-proteobacterial phylotype identified in the global 549 deep-sea hydrothermal vent environments (Takai et al., 2006a)..

550 Taxonomic and ecological implications: The exploration of thermophilic $\mathrm{H}_{2}-$ 551 and/or S-oxidizing chemolithoautotrophs under the piezophilic condition corresponding 552 to an in situ hydrostatic pressure of the TAG hydrothermal field has lead to the 553 successful isolation of previously uncultured, two novel, piezophilic, 554 chemolithoautotrophic Proteobacteria. These new piezophilic chemolithoautotrophs 555 represented the functionally and metabolically significant members in the viable 556 microbial populations and even the numerically considerable components in the 557 microbial community of the black smoker chimney habitat.

558 In this study, the piezophilic cultivation condition was designed to reproduce the 559 in situ hydrostatic pressure but not to reproduce the chemical condition, particularly 560 dissolved concentrations of gaseous energy and carbon sources, of the in situ habitats.

561 The dissimilarity in the chemical conditions may result in the successful enrichment and 562 isolation of novel piezophilic chemolithoautotrophs in this study. This is one aspect of 563 application of the piezophilic cultivation technique to the microbial exploration in the 564 deep-sea and deep subsurface. In contrast, using our piezophilic cultivation technique or 
similar techniques, the nearly complete reproduction of physical and chemical conditions of the in situ habitats in the laboratory could promote to excavate the numerically and functionally dominating but previously uncultivated microorganisms. The isolation of two novel chemolithoautotrophic Proteobacteria from the TAG 569 hydrothermal field is also of great interest from the aspect of systematic and evolutionary bacteriology. Based on the phylogenetic characterization, both strains might represent novel genera of the Proteobacteria. Strain 106 is the first fully characterized S-oxidizing chemolithoautotroph of the phylogenetic group within the Gammaproteobacteria consisting only of the thioautotrophic endosymbionts of the

574 deep-sea animals (Fig. 5). It is a free-living relative evolutionarily related with the 575 endosymbionts although the growth temperature range is a little different between them.

576 Thus, strain 106 will be an excellent comparative research target for elucidating the evolutionary transition between the free-living and symbiotic life forms among the related deep-sea Gammaproteobacteria. Strain 108 is also the first member of the family Rhodobacteraceae, which consists of many chemolithotrophic and phototrophic members (Garrity et al., 2005), from the deep-sea hydrothermal vent environments.

581 Thus, the further investigation of strain 108 may provide an important insight into the

582 metabolic and habitational interaction and evolution associated with interrelationship 583 between the chemolithotrophy, phototrophy and piezophily. Finally, based on physiological and molecular properties of both strains, we propose here new species of new genera named "Thioprofundum lithotrophica" and "Piezobacter thermophilus" for 586 strains 106 and 108, respectively.

Description of Thioprofundum gen. nov.: Thioprofundum (Thi.o.pro'fu.n.dum.

588 Gr. n. thios sulfur; L. n. profundus deep; N.L. neut. n. Thioprofundum sulfur-oxidizer 
589 from deep-sea). Bent to spiral rod. Facultatively anaerobic and piezophilic.

590 Thermophilic and neutrophilic. Chemolithoautotrophic. Able to utilize reduced sulfur

591 compounds as electron donors and nitrate and molecular oxygen as electron acceptors.

$592 \mathrm{NaCl}$ absolutely required for growth. $\mathrm{G}+\mathrm{C}$ content of genomic DNA is about $66 \%$.

593 Major cellular fatty acids are $\mathrm{C}_{16}$, anteiso- $\mathrm{C}_{17}, \mathrm{C}_{18}$ and $\mathrm{C}_{18: 1}$. Based on 16S rRNA gene

594 analysis, the genus Thioprofundum is related to the endosymbionts of the deep-sea

595 animals within the Gammaproteobacteria. The type species is Thioprofundum

596 lithotrophica.

597 Description of Thioprofundum lithotrophica sp. nov.: Thioprofundum

598 lithotrophica (li.tho.tro'phi.ca. Gr. n. lithos stone; Gr. adj. trophikos feeding; N.L. neut.

599 adj. lithotrophica referring to its lithotrophic metabolism). Motile, short bent to long

600 spiral rods with a polar flagellum, with a mean length of 1-20 $\mu \mathrm{m}$ and a mean width of

$601 \quad 0.4-0.6 \mu \mathrm{m}$. Anaerobic to microaerobic. The temperature range for growth is $30{ }^{\circ} \mathrm{C}$ to

$60255{ }^{\circ} \mathrm{C}$ (optimum $50{ }^{\circ} \mathrm{C}$ ). The $\mathrm{pH}$ range for growth is $5.8-7.6$ (optimum growth at $\mathrm{pH}$

603 7.0). $\mathrm{NaCl}$ in the concentration range of $1.2-4.2 \%$ is an absolute growth requirement;

604 optimum growth occurs at 3\%. Strictly chemolithoautotrophic with the reduced sulfur

605 compounds such as elemental sulfur, thiosulfate, tetrathionate or sulfite as an electron

606 donor, and nitrate or molecular oxygen as an electron acceptor. Thiosulfate is oxidized

607 to sulfate and nitrate is reduced to $\mathrm{N}_{2}$ and $\mathrm{N}_{2} \mathrm{O}$ during growth. Nitrate, ammonium,

608 molecular nitrogen or yeast extract are utilized as a sole nitrogen source. The major

609 cellular fatty acids under the conventional pressure condition are $\mathrm{C}_{12}(1.2 \%), \mathrm{C}_{14}(7.2 \%)$,

$610 \mathrm{C}_{15}(2.1 \%), \mathrm{C}_{16}(41.3 \%), \mathrm{C}_{16: 1}(14.3 \%)$, anteiso- $\mathrm{C}_{17}(14.3 \%), \mathrm{C}_{17}(1.2 \%), \mathrm{C}_{18}(4.2 \%)$ and

$611 \mathrm{C}_{18: 1}(14.1 \%)$. The $\mathrm{G}+\mathrm{C}$ content of DNA is about $66 \mathrm{~mol} \%$ (by HPLC). The organism

612 was isolated from a black smoker chimney of the TAG field in the Mid Atlantic Ridge. 
614 Collection of Microorganisms, Institute of Physical and Chemical Research (RIKEN), 615 Japan, and DSM 19353, Deutsche Sammlung von Mikroorganismen und Zellkulturen $616 \mathrm{GmbH}$, Braunschweig, Germany.

617 Description of Piezobacter gen. nov.: Piezobacter (Pie.zo.bac.ter. Gr. v. piezo to 618 press; N.L. masc. n. bacter rod; N.L. masc. n. Piezobacter piezophilic rod). Oval rod. 619 Facultatively anaerobic. Piezophilic. Thermophilic and neutrophilic. Facultatively 620 chemolithoautotrophic. Able to utilize $\mathrm{H}_{2}$ or reduced sulfur compounds as an electron 621 donor and nitrate or molecular oxygen as an electron acceptor. $\mathrm{NaCl}$ absolutely required 622 for growth. $\mathrm{G}+\mathrm{C}$ content of genomic DNA is about $66 \%$. Major cellular fatty acids are $623 \mathrm{C}_{16}, \mathrm{C}_{18}$ and $\mathrm{C}_{18: 1}$. Based on $16 \mathrm{~S}$ rRNA gene analysis, the genus Piezobacter is related 624 to members of the family Rhodobacteraceae within the Alphaproteobacteria. The type 625 species is Piezobacter thermophila. (ther.mo.phi'lus. Gr. adj. thermus hot; Gr. adj. philos loving; N.L. masc. adj. thermophilus heat-loving). Non-motile, short oval rod, with a mean length of $1-1.5 \mu \mathrm{m}$ and a mean width of $0.6-0.7 \mu \mathrm{m}$. Anaerobic to fully aerobic. The temperature range for 630 growth is $30{ }^{\circ} \mathrm{C}$ to $55{ }^{\circ} \mathrm{C}$ (optimum $50{ }^{\circ} \mathrm{C}$ ). The $\mathrm{pH}$ range for growth is $5.5-7.5$ 631 (optimum growth at $\mathrm{pH} 6.5-7.0$ ). $\mathrm{NaCl}$ in the concentration range of $1.2-5.4 \%$ is an absolute growth requirement; optimum growth occurs at $2 \%$. Facultatively 633 chemolithoautotrophic with molecular hydrogen and reduced sulfur compounds such as 634 elemental sulfur, thiosulfate, cystein- $\mathrm{HCl}$, tetrathionate and sulfite as electron donors, 635 and nitrate and molecular oxygen as electron acceptors. Able to grow organotrophically 636 with yeast extract, tryptone, acetate and pyruvate. Chemolithoautotrophic growth is 
637 strictly piezophilic. Thiosulfate is oxidized to sulfate and nitrate is reduced to $\mathrm{N}_{2} \mathrm{O}$

638 during growth. Nitrate, ammonium or molecular nitrogen are utilized as a sole nitrogen

639 source. The major cellular fatty acids under the conventional pressure condition are $\mathrm{C}_{14}$

640 (3.4\%), $\mathrm{C}_{16}(21.4 \%), \mathrm{C}_{18}(37.5 \%)$ and $\mathrm{C}_{18: 1}(37.7 \%)$. The $\mathrm{G}+\mathrm{C}$ content of DNA is

641 about 66 mol\% (by HPLC). The organism was isolated from a black smoker chimney of

642 the TAG field in the Mid Atlantic Ridge.

643 The type strain is Piezobacter thermophilus strain 108, JCM 14636, Japan

644 Collection of Microorganisms, Institute of Physical and Chemical Research (RIKEN), 645 Japan.

646

647 Acknowledgments: First of all, we would like to thank Mr. Katsuyuki Uematsu 648 for assistance in preparing electron micrographs. We are grateful to the captain and 649 crew of the R/V L'Atalante and the operation team of the ROV VICTOR6000 for their 650 technical expertise. We wish to thank onboard scientists of the EXOMAR 2005 cruise 651 for their support onboard.

652

653 


\section{REFERENCES}

654

655 Abe, F., Kato, C., and Horikoshi, K. (1999) Pressure-regulated metabolism in 656 microorganisms. Trends Microbiol 7: 447-453.

657 Amann, R., Binder, B.J., Olson, R.J., Chisholm, S.W., Devereux, R., and Stahl, D.A. 658 (1990) Combination of 16S rRNA-targeted oligonucleotide probes with flow cytometry for analyzing mixed microbial populations. Appl Environ Microbiol 56:

660 $\underline{1919-1925}$

661 Bernhardt, G., Disteche, A., Jaenicke, R., Koch, B., Lüdemann, H.-D., and Stetter, K.O. 662 (1988) Effect of carbon dioxide and hydrostatic pressure on the $\mathrm{pH}$ of culture media 663 and the growth of methanogens at elevated temperature. Appl Microbiol Biotechnol 664 28: $176-181$.

665 Campbell, A.C., Palmer, M.R., Klinkhammer, G.P., Bowers, T.S., Edmond, J.M., 666 Lawrence, J.L., et al. (1988) Chemistry of hot springs on the Mid-Atlantic Ridge. $667 \quad$ Nature 335: 514-519.

668 Charlou, J.L., Donval, J.P., JeanBaptiste, P., Dapoigny, A., and Rona, P.A. (1996) 669 Gases and helium isotopes in high temperature solutions sampled before and after 670 ODP Leg 158 drilling at TAG hydrothermal field (26 N, MAR). Geophys Res Lett $671 \quad$ 23: $3491-3494$.

672 Charlou, J.L., Donval, J.P., Fouquet, Y., Jean-Baptiste, P., and Holm, N. (2002) 673 Geochemistry of high $\mathrm{H}_{2}$ and $\mathrm{CH}_{4}$ vent fluids issuing from ultramafic rocks at the 674 Rainbow hydrothermal field (36²'N, MAR). Chem Geol 191: 345-359.

675 Chiba, H., Masuda, H., Lee, S.-Y., and Fujioka, K. (2001) Chemistry of hydrothermal 676 fluids at the TAG active mound, MAR $26^{\circ} \mathrm{N}$, in 1998. Geophys Res Lett, 28: 
678 DeLong, E.F. (1992) Archaea in coastal marine environments. Proc Natl Acad Sci USA 679 89: 5685-5689.

680 DeLong, E.F., and Yayanos, A.A. (1985) Adaptation of the membrane lipids of a 681 deep-sea bacterium to changes in hydrostatic pressure. Science 228: 1101-1103.

682 DeLong, E.F., and Yayanos, A.A. (1986) Biochemical function and ecological 683 significance of novel bacterial lipids in deep-sea prokaryotes. Appl Environ Microbiol $684 \quad$ 51: 730-737.

685 Deming, J.D., and Baross, J.A. (1993) Deep-sea smokers: eindows to a subsurface 686 biosphere? Geochim Cosmochim Acta 57: 3219-3230.

687 Garrity, G.M., Bell, J.A., and Lilburn, T. (2005) Family I. Rhodobacteraceae fam. nov. 688 In Bergey's manual of systematic bacteriology. $2^{\text {nd }}$ edition. vol. 2. part C. Brenner, 689 D.J., Krieg, N.R., and Staley, J.T. (eds) Springer. New York. p. 161.

690 Kato, C. (2006) Handling of piezophilic microorganisms. In Extremophiles. Methods in 691 Microbiology vol. 35. Rainey, F.A., and Oren, A. (eds) Elsevier. London. p. 733-741. 692 La, H.J., Im, W.T., Ten, L.N., Kang, M.S., Shin, D.Y., and Lee, S.T. Paracoccus 693 koreensis sp. nov., isolated from anaerobic granules in an upflow anaerobic sludge 694 blanket (UASB) reactor. Int J Syst Evol Microbiol 55: 1657-1660.

695 Lane, D.J. (1985) 16S/23S sequencing. In Nucleic Acid Techniques in Bacterial 696 Systematics.Stackbrandt, E., and Goodfellow, M. (eds) John Wiley and Sons. New 697 York. p. 115-176.

698 Ludwig, W., Strunk, O., Westram, R., Richter, L., Yadhukumar, H.M., Buchner, A., et 699 al. (2004) ARB: a software environment for sequence data. Nucleic Acids Res 32: $700 \quad 1363-1371$. 
701 Lupton, J., Lilley, M., Butterfield, D., Evans, L., Embley, R., Massoth, G., Christenson,

702 B., Nakamura, K., and Schmidt, M. (2008) Venting of a separate $\mathrm{CO}_{2}$-rich gas phase

703 from submarine arc volcanoes: Examples from the Mariana and Tonga-Kermadec

$704 \quad$ arcs. J Geophys Res 113: B08S12 (doi:10.1029/2007JB005467).

705 Mangelsdorf, K., Zink, K.-G., Birrien, J.-L., and Toffin, L. (2005) A quantitative 706 assessment of pressure dependent adaptive changes in the membrane lipids of a 707 piezosensitive deep sub-seafloor bacterium. Org Geochem 36: 1459-1479.

708 Marmur, J., and Doty, P. (1962) Determination of the base composition of 709 deoxyribonucleic acid from its thermal denaturation temperature. J Mol Biol 5: $710 \quad 109-118$.

711 McCollom, T.M., and Shock, E.L. (1997) Geochemical constraints on 712 chemolithoautotrophic metabolism by microorganisms in seafloor hydrothermal $713 \quad$ systems. Geochim Cosmochim Acta 61: 4375-4391.

714 Miller, J.F., Shah, N.N., Nelson, C.M., Ludlow, J.M., and Clark, D.S. (1988) Pressure 715 and temperature effects on growth and methane production of the extreme 716 thermophile Methanococcus jannaschii. Appl Environ Microbiol 54: 3039-3042.

717 Nakagawa, S., and Takai, K. (2006) The isolation of thermophiles from deep-sea 718 hydrothermal environments. In Extremophiles. Methods in Microbiology vol. 35. 719 Rainey, F.A., and Oren, A. (eds) Elsevier. London. p. 57-91.

720 Nakagawa, S., and Takai, K. (2008) Deep-sea vent chemolithoautotrophs: diversity, 721 biochemistry and ecological significance. FEMS Microbiol Ecol 65: 1-14.

722 Park, C.B., Boonyaratanakornkit, B.B., and Clark, D.S. (2006) Toward the large scale 723 cultivation of hyperthermophiles at high-temperature and high-pressure. In 724 Extremophiles. Methods in Microbiology vol. 35. Rainey, F.A., and Oren, A. (eds) 
Elsevier. London. p. 109-126.

726 Person, A., Seewald, J.S., and Eglinton, T.I. (2005) Bacterial incorporation of relict

727 carbon in the hydrothermal environment of Guaymas Basin. Geochim Cosmochim $728 \quad$ Acta 69: 5477-5486.

729 Postec, A., Urios, L., Lesongeur, F., Ollivier, B., Quérellou, J., and Godfroy, A. (2005)

730 Continuous enrichment culture and molecular monitoring to investigate the microbial

731 diversity of thermophiles inhabiting the deep-sea hydrothermal ecosystems. Curr

$732 \quad$ Microbiol 50: 138-144.

733 Sekiguchi, Y., Kamagata, Y., Nakamura, K., Ohashi, A., and Harada, H. (1999)

$734 \quad$ Fluorescence in situ hybridization using 16S rRNA-targeted oligonucleotides reveals

735 localization of methanogens and selected uncultured bacteria in mesophilic and

736 thermophilic sludge granules. Appl Environ Microbiol 65: 1280-1288.

737 Shock, E.L., and Holland, M.E. (2006) Geochemical energy sources that support the

738 subsurface biosphere. In Back-Arc spreading systems: geological, biological, 739 chemical and physical interactions, Geophys Monogr Ser vol. 166. Christie, D.M.,

740 Fisher, C.R., Lee, S.M., Givens, S. (eds) AGU. Washington DC. p. 153-165.

741 Stahl, D.A., and Amann, R. (1991) Development and application of nucleic acid probes.

742 In Nucleic acid techniques in bacterial systematics, Stackebrandt, E., Goodfellow, M.

743 (eds) John Wiley \& Sons, Inc., New York, NY. p. 205-248.

744 Suzuki, Y., Sasaki, T., Suzuki, M., Tsuchida, S., Nealson, K.H., and Horikoshi, K.

745 (2005) Molecular phylogenetic and isotopic evidence of two lineages of

746 chemoautotrophic endosymbionts distinct at the subdivision level harbored in one

747 host-animal type: the genus Alviniconcha (Gastropoda: Provannidae). FEMS

$748 \quad$ Microbiol Lett 249: 105-112. 
Takai K, and Horikoshi K. (2000) Thermosipho japonicus sp. nov., an extremely

750 thermophilic bacterium isolated from a deep-sea hydrothermal vent in Japan. $751 \quad$ Extremophiles 4: 9-17.

752 Takai, K., Sugai, A., Itoh, Y., Horikoshi, K. (2000) Palaeococcus ferrophilus gen. nov., 753 sp. nov., a barophilic, hyperthermophilic archaeon from a deep-sea hydrothermal vent 754 chimney. Int J Syst Evol Microbiol 50: 489-500.

755 Takai, K., Komatsu, T., Inagaki, F., and Horikoshi, K. (2001) Distribution of Archaea in 756 a black smoker chimney structure. Appl Environ Microbiol 67: 3618-3629.

757 Takai, K., Inagaki, F., Nakagaw,a S., Hirayama, H., Nunoura, T., Sako, Y., et al. (2003) 758 Isolation and phylogenetic diversity of members of previously uncultivated 759 epsilon-Proteobacteria in deep-sea hydrothermal fields. FEMS Microbiol Lett 218: $760 \quad 167-174$.

761 Takai, K., Gamo, T., Tsunogai, U., Nakayama, N., Hirayama, H., Nealson, K.H., and 762 Horikoshi K. (2004) Geochemical and microbiological evidence for a 763 hydrogen-based, hyperthermophilic subsurface lithoautotrophic microbial ecosystem 764 (HyperSLiME) beneath an active deep-sea hydrothermal field. Extremophiles 8: 765 269-282.

766 Takai, K., Nakagawa, S., Reysenbach, A.L., and Hoek, J. (2006a) Microbial ecology of 767 Mid-Ocean Ridges and Back-Arc Basins. In Back-Arc spreading systems: geological, 768 biological, chemical and physical interactions, Geophys Monogr Ser vol. 166. 769 Christie, D.M., Fisher, C.R., Lee, S.M., Givens, S. (eds) AGU. Washington DC. p. 770 185-213.

771 Takai, K., Miyazaki, M., Nunoura, T., Hirayama, H., Oida, H., Furushima, Y., 772 Yamamoto, H., Horikoshi, K. (2006b) Sulfurivirga caldicuralii gen. nov., sp. nov., a 
novel microaerobic, thermophilic, thiosulfate-oxidizing chemolithoautotroph, isolated from a shallow marine hydrothermal system occurring in a coral reef, Japan. Int $\mathbf{J}$ Syst Evol Microbiol 56:1921-1929.

Takai, K., Nakamura, K., Toki, T., Tsunogai, T., Miyazaki, M., Miyazaki, J., et al. (2008a) Cell proliferation at $122{ }^{\circ} \mathrm{C}$ and isotopically heavy $\mathrm{CH}_{4}$ production by a hyperthermophilic methanogen under high pressures cultivation. Proc Natl Acad Sci USA 105: 10949-10954.

Takai, K., Nunoura, T., Ishibashi, J., Lupton, J., Suzuki, R., Hamasaki, H., et al. (2008) Variability in the microbial communities and hydrothermal fluid chemistry at the newly-discoverred Mariner hydrothermal field, southern Lau Basin. J Geophys Res 113: G02031 (doi:10.1029/2007JG000636).

Tamaoka, J., and Komagata, K. (1984) Determination of DNA base composition by 785 reversed-phase high-performance liquid chromatography. FEMS Microbiol Lett 25: $125-128$.

Tivey, M.K. (2006) Environmental conditions within active seafloor vent structures: sensitivity to vent fluid composition and fluid flow. In Back-Arc spreading systems: geological, biological, chemical and physical interactions, Geophys Monogr Ser vol. 166. Christie, D.M., Fisher, C.R., Lee, S.M., Givens, S. (eds) AGU. Washington DC. p. $137-152$.

Zillig, W., Holz, I., Janekovic, D., Klenk, H.-P., Imsel, E., Trent, J., Wunderl, S., Forjaz,

793 V.H., Coutinho, R. and Ferreira, T. (1990) Hyperthermus butylicus, a 794 hyperthermophilic sulfur-reducing archaebacterium that ferments peptides. $J$ $795 \quad$ Bacteriol 172: 3959-3965.

796 Zobell, C.E., and Morita, R.Y. (1957) Barophilic bacteria in some deep sea sediments. J 
Bacteriol 73: 563-568. 
798 Table 1. Medium and condition of liquid serial dilution cultures.

\begin{tabular}{|c|c|c|c|c|c|c|c|}
\hline Medium & $\begin{array}{c}\text { Gas phase } \\
\text { (gas pressure or } \\
\text { hydrostatic pressure) }\end{array}$ & $\begin{array}{c}\text { Cultivation } \\
\text { temperature } \\
\left({ }^{\circ} \mathrm{C}\right) \\
\end{array}$ & $\begin{array}{c}\text { pH } \\
\text { of } \\
\text { medium }\end{array}$ & $\begin{array}{l}\text { Possible } \\
\text { electron } \\
\text { donor } \\
\end{array}$ & $\begin{array}{l}\text { Possible } \\
\text { electron } \\
\text { acceptor }\end{array}$ & $\begin{array}{c}\text { Subsamples } \\
\text { inoculated }\end{array}$ & Reference \\
\hline MJYPS & $100 \% \mathrm{~N}_{2}(0.2 \mathrm{MPa})$ & $55,70,85,95$ & 7 & $\mathrm{YE}^{*}, \mathrm{TT} \dagger$ & $\mathrm{e}_{\mathrm{NO}}, \mathrm{SO}_{4}, \mathrm{~S}^{0}$, fermentation & With sodium sulfide & Takai et al., 2000 \\
\hline MMJHS & $\begin{array}{c}80 \% \mathrm{H}_{2}+19 \% \mathrm{CO}_{2}+1 \% \mathrm{O}_{2} \\
(0.2 \mathrm{MPa})\end{array}$ & $30,50,55,70,85,95$ & 6.5 & $\mathrm{H}_{2}, \mathrm{~S}^{0}, \mathrm{~S}_{2} \mathrm{O}_{3}$ & $\mathrm{O}_{2}, \mathrm{~S}^{0}, \mathrm{~S}_{2} \mathrm{O}_{3}, \mathrm{NO}_{3}, \mathrm{CO}_{2}$ & Without sodium sulfide & Takai et al., 2003 \\
\hline Piezo-MMJHS & $\begin{array}{c}10 \mathrm{mM} \mathrm{H}_{2}, 30 \mathrm{mM} \Sigma \mathrm{CO}_{2} \\
(36 \mathrm{MPa})\end{array}$ & 50 & 6.5 & $\mathrm{H}_{2}, \mathrm{~S}^{0}, \mathrm{~S}_{2} \mathrm{O}_{3}$ & $\mathrm{~S}^{0}, \mathrm{~S}_{2} \mathrm{O}_{3}, \mathrm{NO}_{3}, \mathrm{CO}_{2}$ & Without sodium sulfide & In this study \\
\hline
\end{tabular}

$799 *$ *E means yeast extract.

$800+$ TT means tryptone.

801

802 


\begin{tabular}{|c|c|c|c|c|}
\hline Electron donor/acceptor: & $\begin{array}{l}\text { Strain } 106 \\
\text { Piezophilic } \\
\text { condition } \\
\text { at } 16 \mathrm{MPa}\end{array}$ & $\begin{array}{c}\text { Strain 106 } \\
\text { Non-piezophilic } \\
\text { condition } \\
\text { at } 0.2 \mathrm{MPa} \text { gas } \\
\text { pressure } \\
\end{array}$ & $\begin{array}{l}\text { Strain } 108 \\
\text { Piezophilic } \\
\text { condition } \\
\text { at } 36 \mathrm{MPa}\end{array}$ & $\begin{array}{c}\text { Strain 108 } \\
\text { Non-piezophilic } \\
\text { condition } \\
\text { at } 0.2 \mathrm{MPa} \text { gas } \\
\text { pressure } \\
\end{array}$ \\
\hline $\mathrm{H}_{2}(10 \mathrm{mM}) / \mathrm{NO}_{3}(20 \mathrm{mM})$ & "N.G.* & N.A. $\dagger$ & $+\S$ & N.A. \\
\hline $\mathrm{H}_{2}(80 \% ; \mathrm{v} / \mathrm{v}) / \mathrm{NO}_{3}(20 \mathrm{mM})$ & N.A. & N.G. & N.A. & N.G. \\
\hline $\mathrm{H}_{2}(80 \% ; \mathrm{v} / \mathrm{v}) / \mathrm{O}_{2}(1 \% ; \mathrm{v} / \mathrm{v})$ & N.A & N.G. & N.A & N.G. \\
\hline $\mathrm{H}_{2}(10 \mathrm{mM}) / \mathrm{S}^{0}(3 \% ; \mathrm{w} / \mathrm{v})$ & N.G. & N.A & N.G. & N.A. \\
\hline $\mathrm{H}_{2}(10 \mathrm{mM}) / \mathrm{S}_{2} \mathrm{O}_{3}(10 \mathrm{mM})$ & N.G. & N.A & N.G. & N.A. \\
\hline $\mathrm{S}^{0}(3 \% ; \mathrm{w} / \mathrm{v}) / \mathrm{NO}_{3}(20 \mathrm{mM})$ & ++ & ++ & ++ & N.G. \\
\hline $\mathrm{S}_{2} \mathrm{O}_{3}(10 \mathrm{mM}) / \mathrm{NO}_{3}(20 \mathrm{mM})$ & ++ & ++ & ++ & N.G. \\
\hline $\mathrm{S}_{2} \mathrm{O}_{3}(10 \mathrm{mM}) / \mathrm{NO}_{2}(2.5 \mathrm{mM})$ & N.G. & N.G. & N.G. & N.G. \\
\hline $\mathrm{S}_{2} \mathrm{O}_{3}(10 \mathrm{mM}) / \mathrm{O}_{2}(0.04 \mathrm{mM})$ & ++ & N.A & ++ & N.A \\
\hline $\mathrm{S}_{2} \mathrm{O}_{3}(10 \mathrm{mM}) / \mathrm{O}_{2}(0.12 \mathrm{mM})$ & + & N.A & ++ & N.A \\
\hline $\mathrm{S}_{2} \mathrm{O}_{3}(10 \mathrm{mM}) / \mathrm{O}_{2}(0.4 \mathrm{mM})$ & + & N.A & ++ & N.A \\
\hline $\mathrm{S}_{2} \mathrm{O}_{3}(10 \mathrm{mM}) / \mathrm{O}_{2}(1.2 \mathrm{mM})$ & N.G. & N.A & ++ & N.A \\
\hline $\mathrm{S}_{2} \mathrm{O}_{3}(10 \mathrm{mM}) / \mathrm{O}_{2}(2 \mathrm{mM})$ & N.G. & N.A & ++ & N.A \\
\hline $\mathrm{S}_{2} \mathrm{O}_{3}(10 \mathrm{mM}) / \mathrm{O}_{2}(4 \mathrm{mM})$ & N.G. & N.A & ++ & N.A \\
\hline $\mathrm{S}_{2} \mathrm{O}_{3}(10 \mathrm{mM}) / \mathrm{O}_{2}(0.1 \% ; \mathrm{v} / \mathrm{v})$ & N.A & ++ & N.A & N.G. \\
\hline $\mathrm{S}_{2} \mathrm{O}_{3}(10 \mathrm{mM}) / \mathrm{O}_{2}(0.3 \% ; \mathrm{v} / \mathrm{v})$ & N.A & ++ & N.A & N.G. \\
\hline $\mathrm{S}_{2} \mathrm{O}_{3}(10 \mathrm{mM}) / \mathrm{O}_{2}(1 \% ; \mathrm{v} / \mathrm{v})$ & N.A & +++ & N.A & N.G. \\
\hline $\mathrm{S}_{2} \mathrm{O}_{3}(10 \mathrm{mM}) / \mathrm{O}_{2}(3 \% ; \mathrm{v} / \mathrm{v})$ & N.A & +++ & N.A & N.G. \\
\hline $\mathrm{S}_{2} \mathrm{O}_{3}(10 \mathrm{mM}) / \mathrm{O}_{2}(5 \% ; \mathrm{v} / \mathrm{v})$ & N.A & +++ & N.A & N.G. \\
\hline $\mathrm{S}_{2} \mathrm{O}_{3}(10 \mathrm{mM}) / \mathrm{O}_{2}(10 \% ; \mathrm{v} / \mathrm{v})$ & N.A & N.G. & N.A & N.G. \\
\hline $\mathrm{H}_{2} \mathrm{~S}+\mathrm{HS}(1.25 \mathrm{mM}) / \mathrm{NO}_{3}(20 \mathrm{mM})$ & ++ & ++ & ++ & N.G. \\
\hline Cys- $\mathrm{HCl}(2.5 \mathrm{mM}) / \mathrm{NO}_{3}(20 \mathrm{mM})$ & N.G. & N.G. & ++ & N.G. \\
\hline $\mathrm{S}_{4} \mathrm{O}_{6}(5 \mathrm{mM}) / \mathrm{NO}_{3}(20 \mathrm{mM})$ & + & + & ++ & N.G. \\
\hline $\mathrm{SO}_{3}(2.5 \mathrm{mM}) / \mathrm{NO}_{3}(20 \mathrm{mM})$ & + & + & ++ & N.G. \\
\hline Yeast Extract $(0.1 \% ; \mathrm{w} / \mathrm{v}) / \mathrm{NO}_{3}(20 \mathrm{mM})$ & N.G. & N.G. & +++ & ++ \\
\hline Tryptone $(0.1 \%, \mathrm{w} / \mathrm{v}) / \mathrm{NO}_{3}(20 \mathrm{mM})$ & N.G. & N.G. & +++ & ++ \\
\hline Casamino acid $(0.1 \%, \mathrm{w} / \mathrm{v}) / \mathrm{NO}_{3}(20 \mathrm{mM})$ & N.G. & N.G. & N.G. & N.G. \\
\hline Formate $(5 \mathrm{mM}) / \mathrm{NO}_{3}(20 \mathrm{mM})$ & N.G. & N.G. & N.G. & N.G. \\
\hline Acetate $(5 \mathrm{mM}) / \mathrm{NO}_{3}(20 \mathrm{mM})$ & N.G. & N.G. & +++ & ++ \\
\hline Pyruvate $(5 \mathrm{mM}) / \mathrm{NO}_{3}(20 \mathrm{mM})$ & N.G. & N.G. & +++ & ++ \\
\hline Yeast Extract $(0.1 \% ; \mathrm{w} / \mathrm{v}) / \mathrm{O}_{2}(0.3 \% ; \mathrm{v} / \mathrm{v})$ & N.A & N.G. & N.A & ++ \\
\hline Yeast Extract $(0.1 \% ; \mathrm{w} / \mathrm{v}) / \mathrm{O}_{2}(1 \% ; \mathrm{v} / \mathrm{v})$ & N.A & N.G. & N.A & +++ \\
\hline Yeast Extract $(0.1 \% ; \mathrm{w} / \mathrm{v}) / \mathrm{O}_{2}(3 \% ; \mathrm{v} / \mathrm{v})$ & N.A & N.G. & N.A & +++ \\
\hline Yeast Extract $(0.1 \% ; \mathrm{w} / \mathrm{v}) / \mathrm{O}_{2}(5 \% ; \mathrm{v} / \mathrm{v})$ & N.A & N.G. & N.A & +++ \\
\hline Yeast Extract $(0.1 \% ; \mathrm{w} / \mathrm{v}) / \mathrm{O}_{2}(10 \% ; \mathrm{v} / \mathrm{v})$ & N.A & N.G. & N.A & +++ \\
\hline Yeast Extract $(0.1 \% ; \mathrm{w} / \mathrm{v}) / \mathrm{O}_{2}(20 \% ; \mathrm{v} / \mathrm{v})$ & N.A & N.G. & N.A & +++ \\
\hline
\end{tabular}

*N.G.; not grown.

$806 \dagger$ N.A.; not attempted.

$807 \S+$; final cell yield is $<1.0 \times 10^{8}$ cells $/ \mathrm{ml},++$; between $1.0 \times 10^{8}$ and $5.0 \times 10^{8},+++;>1.0 \times 10^{9}$.

808 
811 Table 3. Cellular fatty acid compositions of strains 106 and 108 under the piezophilic 812 and non-piezophilic cultivation conditions.

\begin{tabular}{|c|c|c|c|c|}
\hline Fatty acids & $\begin{array}{c}\text { Strain } 106 \\
\text { Autotrophically } \\
\text { grown at } 16 \mathrm{MPa}\end{array}$ & $\begin{array}{c}\text { Strain } 106 \\
\text { Autotrophically } \\
\text { grown at } 0.2 \mathrm{MPa} \\
\text { (gas pressure) }\end{array}$ & $\begin{array}{c}\text { Strain } 108 \\
\text { Autotrophically } \\
\text { grown at } 36 \mathrm{MPa}\end{array}$ & $\begin{array}{c}\text { Strain 108 } \\
\text { Organotrophically } \\
\text { grown at 0.1 MPa } \\
\text { (air) }\end{array}$ \\
\hline $\mathrm{C}_{12}$ & $1.2 \%$ & $1.8 \%$ & n.d.* & n.d. \\
\hline $\mathrm{C}_{14}$ & $7.2 \%$ & $4.7 \%$ & $3.4 \%$ & $3.2 \%$ \\
\hline $\mathrm{C}_{15}$ & $2.1 \%$ & $1.9 \%$ & n.d. & n.d. \\
\hline $\mathrm{C}_{16}$ & $41.3 \%$ & $41.3 \%$ & $21.4 \%$ & $26.8 \%$ \\
\hline$C_{16: 1 \omega 7}$ & $14.3 \%$ & $5.3 \%$ & n.d. & n.d. \\
\hline Anteiso $\mathrm{C}_{17}$ & $14.3 \%$ & $17.1 \%$ & n.d. & n.d. \\
\hline $\mathrm{C}_{17}$ & $1.2 \%$ & 1.1 & n.d. & n.d. \\
\hline $\mathrm{C}_{18}$ & $4.2 \%$ & $10.9 \%$ & $37.5 \%$ & $42.0 \%$ \\
\hline $\mathrm{C}_{18: 1 \omega 2}$ & n.d. & n.d. & $16.5 \%$ & $12.2 \%$ \\
\hline $\mathrm{C}_{18: 1 \omega 7}$ & $14.1 \%$ & $15.9 \%$ & $21.2 \%$ & $15.8 \%$ \\
\hline Total & $99.9 \%$ & $100 \%$ & $100 \%$ & $100 \%$ \\
\hline $\mathrm{UF} / \mathrm{SF} \dagger$ & 0.397 & 0.269 & 0.605 & 0.389 \\
\hline $\mathrm{C}_{\text {average }} \S$ & 16.29 & 16.52 & 17.44 & 17.34 \\
\hline
\end{tabular}

$813 *$ *n.d.; not detected.

$814 \dagger \mathrm{UF} / \mathrm{SF}$; unsaturated fatty acids/saturated fatty acids.

$815 \S \mathrm{C}_{\text {average }}$; An average carbon chain number of fatty acids.

816 
818 Figure 1. Electron micrographs of negatively stained cell of strain 106 grown under the

819 piezophilic cultivation condition at $50{ }^{\circ} \mathrm{C}$ and $16 \mathrm{MPa}$ (a) and under the non-piezophilic 820 cultivation condition at $50{ }^{\circ} \mathrm{C}$ and $0.2 \mathrm{MPa}$ of gas pressure $\left(80 \% \mathrm{H}_{2}+20 \% \mathrm{CO}_{2}\right)(\mathrm{b})$, 821 and of strain 108 grown under the piezophilic cultivation condition at $50{ }^{\circ} \mathrm{C}$ and $16 \mathrm{MPa}$ 822 (c). Bar indicates $2.0 \mu \mathrm{m}$ (a) and $1.0 \mu \mathrm{m}$ (b and c), respectively.

823

824 Figure 2. Effects of temperature (a), $\mathrm{pH}(\mathrm{b})$ and $\mathrm{NaCl}$ concentration (c) on growth of 825 strain $106(\bullet)$ or strain $108(\square)$. (a) Growth curves at different temperatures were 826 determined in Piezo-MMJHS medium at pH 6.5 at the optimal pressures. (b) Effect of $827 \mathrm{pH}$ on growth was determined in Piezo-MMJHS medium having varying $\mathrm{pH}$ at $50{ }^{\circ} \mathrm{C}$ 828 and the optimal pressures. The $\mathrm{pH}$ value was monitored before $(\bullet$ and $\square$ ) and after ( $\circ$ 829 and $\mathbf{m}$ ) the growth. (c) Effect of $\mathrm{NaCl}$ concentration on growth was determined in 830 Piezo-MMJHS medium containing a varying concentration of $\mathrm{NaCl}$ at $50{ }^{\circ} \mathrm{C}$ and $\mathrm{pH} 6.0$ 831 under the piezophilic condition.

832

833 Figure 3. Effect of hydrostatic pressure on growth of strains $106(\bullet)$ or $108(\square)$. Growth 834 curves were determined at $50{ }^{\circ} \mathrm{C}$ and $\mathrm{pH} 6.5$ under the autotrophic growth condition.

835

836 Figure 4. Time course of oxidation of electron donor, reduction of electron acceptor 837 and concomitant growth of strain 106 grown with thiosulfate and nitrate (a), strain 108 838 grown with $\mathrm{H}_{2}$ and nitrate (b) or strain 108 grown with thiosulfate and nitrate (c). (a) 839 Consumption of thiosulfate and nitrate, production of sulfate and nitrogenous gases and 840 cellular proliferation of strain 106 were determined at $50{ }^{\circ} \mathrm{C}, \mathrm{pH} 6.5$ and $16 \mathrm{MPa}$. (b) 841 Consumption of $\mathrm{H}_{2}$ and nitrate, production of nitrogenous gases and cellular 842 proliferation of strain 108 were determined at $50{ }^{\circ} \mathrm{C}, \mathrm{pH} 6.5$ and $36 \mathrm{MPa}$. The 843 concentration $\mathrm{N}_{2} \mathrm{O}$ is indicated as 5 times higher value for easy perception. (c) 844 Consumption of thiosulfate and nitrate, production of nitrogenous gases and cellular 845 proliferation of strain 108 were determined at $50{ }^{\circ} \mathrm{C}, \mathrm{pH} 6.5$ and $36 \mathrm{MPa}$.

846

847 Figure 5. Phylogenetic tree of representative species and endosymbionts within the 848 Alphaproteobacteria and Gammaproteobacteria including strain 106 and 108. The tree 849 was inferred from 16S rRNA gene sequences using the neighbor-joining method on the 8501022 homologous sequence positions for each sequence. The number at each node 851 represents the bootstrap value (in percent) determined by 1000 replicates. The scale bar 
852 indicates 5 substitutions per 100 nucleotides.

853 

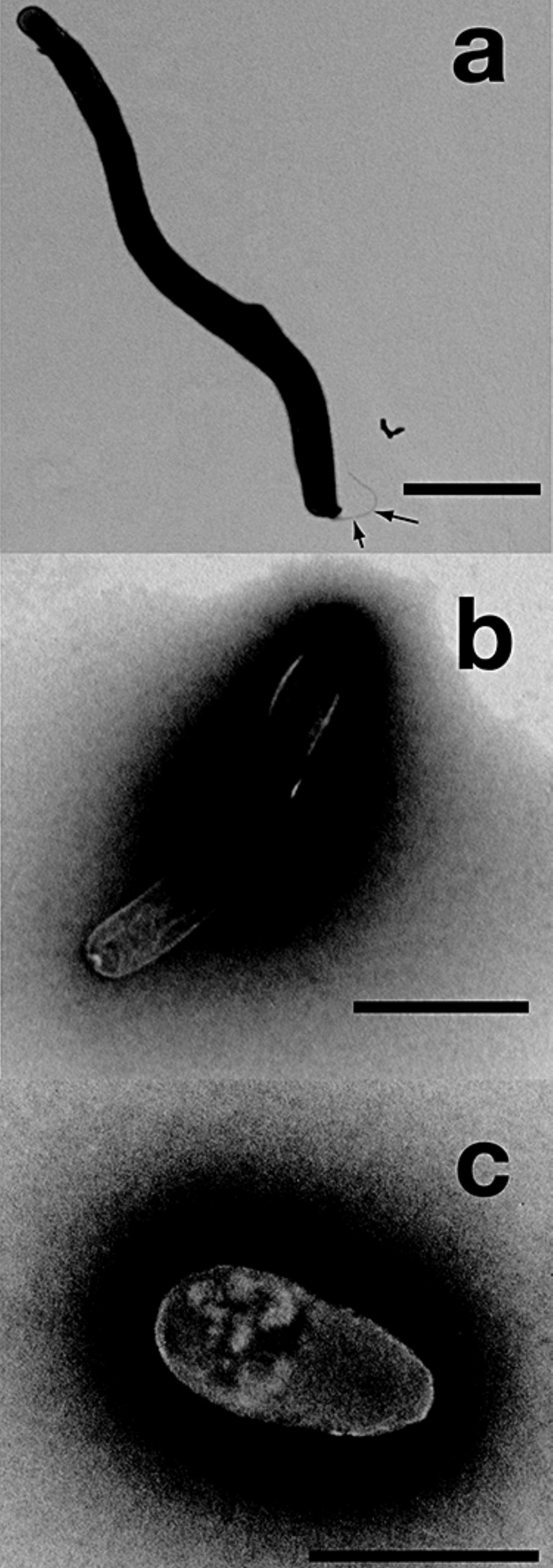

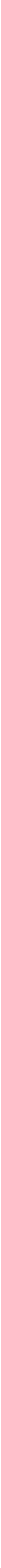


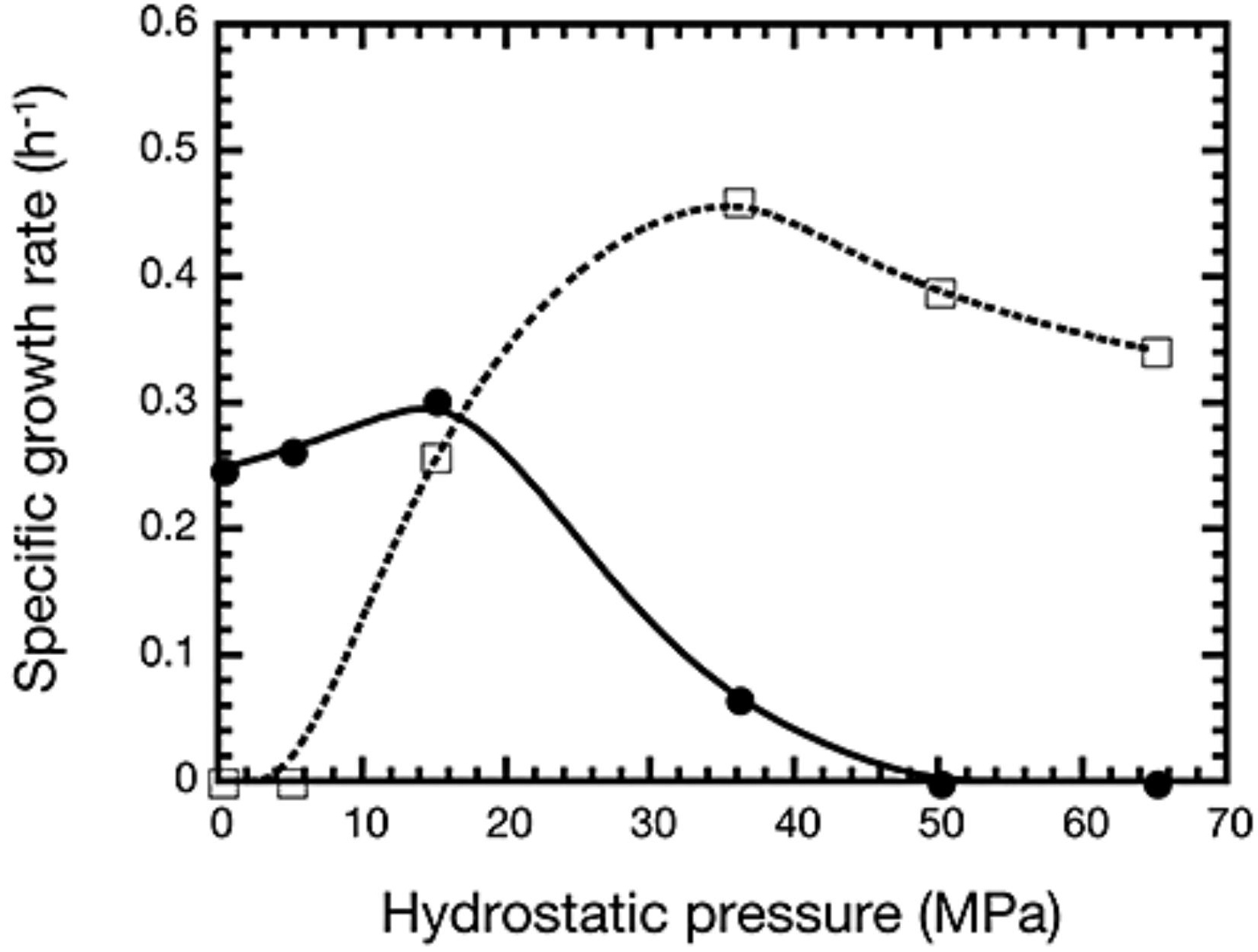











